Journal of Research in Interprofessional

Practice and

Education

Vol. 4.2

November 2014

\section{Healthcare Student Stereotypes: A Systematic Review with Implications for Interprofessional Collaboration}

\author{
Karey Cook, PT, DPT \& Judith Stoecker, PT, PhD
}

\begin{abstract}
Background: Stereotyping is one factor theorized to facilitate or inhibit effective interprofessional healthcare education and collaboration. The purpose of this article is to systematically review the literature to determine what stereotypes are present among healthcare students about other healthcare students and practitioners.

Methods and Findings: A search of nine electronic databases identified studies that examined stereotypes among healthcare students. Studies were included if they met three search criteria: utilized quantitative methods; collected data on the stereotypes of healthcare students, including medical students, toward other healthcare students or healthcare practitioners; and included participants who were enrolled in a professional healthcare program. Thirteen studies were identified for this review. The results demonstrate that students of various healthcare professions hold stereotypes characterized by both positive and negative adjectives of students and practitioners in their own and other healthcare professions.

Conclusions: Students enrolled in healthcare programs hold various stereotypes of other healthcare students and practitioners. The presence of these stereotypes among students may have an influence on patterns of communication and collaboration during future practice in the healthcare environment.
\end{abstract}

Keywords: Stereotypes; Interprofessional; Healthcare students; Healthcare education

\section{Introduction}

It has been suggested that working as a collaborative, interprofessional team is essential to providing effective, patient-centred care. There are many factors theorized to facilitate or inhibit effective healthcare collaboration and interprofessional education, one of which is stereotyping. As a psychological concept, stereotyping is neither positive nor negative. It is a useful way of organizing information about different groups and promoting efficient interactions between members of different groups $[1,2]$. However, stereotypes can also interfere with collaboration by impacting communication between groups [3-6]. Multiple studies have reported that stereotypes are held by various healthcare providers both within professions and among different professions $[1,2,4,6,7]$. It has also been demonstrated in the literature that healthcare students hold stereotypes about members of other healthcare professions, and these stereotypes may be present when students first enter professional healthcare education [1-4,7]. Stereotypes held by healthcare students may affect interactions and communication while students are in school as well as after graduation $[1,2,3,7,8]$. Therefore, it is important to examine stereotypes of healthcare students that interfere with communication and collaboration in the classroom and ultimately in the clinic. The purpose of this article is to systematically review the litera-

\section{Journal of Research in Interprofessional Practice and Education (JRIPE)


Healthcare Student Stereotypes

Cook \& Stoecker

Journal of Research in Interprofessional Practice and Education

Vol. 4.2 November 2014

\section{Journal of Research in Interprofessional Practice and Education}

ture to determine what stereotypes are held by healthcare students about other healthcare students and practitioners.

\section{Methods}

Electronic databases were searched to identify studies that examined stereotypes among healthcare students toward other healthcare students and healthcare practitioners. These databases were: Consumer Health Complete, Healthsource, Psychiatry Online, Academic Search Premier, Professional Development Collection, ProQuest Health and Medical Complete, ProQuest Nursing and Allied Health, Medline, and CINAHL. Each database was searched from inception through August 2011. In addition, the Physical Therapy Journal was searched from 1980 through August 2011, and the Journal of Physical Therapy Education was searched from 1999 through spring 2011. The following search terms were used: healthcare students and stereotypes, professional stereotypes, health profession students and stereotypes, healthcare practitioners and stereotypes, health profession practitioners and stereotypes, healthcare professionals and stereotypes. Articles were initially screened for inclusion in this narrative review based on title and abstract, if available.

\section{Study selection}

The first reviewer completed all database searches. All articles that met the inclusion criteria based on title and/or abstract according to the first reviewer were independently reviewed by a second reviewer based on title and/or abstract. Any questions about the titles/abstracts in relation to the criteria were identified independently by both reviewers, and the first reviewer obtained the full-text article to answer these questions. These articles were then sent back to the second reviewer for approval as needed. Reference lists of the included articles were then reviewed by the first reviewer, and articles were evaluated against the inclusion criteria based on title and/or abstract. The same process of independent review by the second reviewer was carried out for all articles identified through reference list reviews.

Studies were included if they met three search criteria: utilized quantitative methods; collected data on the stereotypes of healthcare students, including medical students, toward other healthcare students or healthcare practitioners; and included participants who were enrolled in a professional healthcare program. Studies were excluded upon initial review if they examined stereotypes held by practicing healthcare providers; stereotypes based on gender, ethnicity, sexual orientation, race, age, or any other attribute other than healthcare profession; or stereotypes held by high school students.

The initial list of included articles was then reviewed specifically based on exclusion criteria. Articles were excluded if they were qualitative or mixed-methods, or if they examined:

- constructs other than stereotypes of healthcare students. For example, a study that examined the effectiveness of an interprofessional education program by reporting students' views of changes in their 


\section{JRIPE}

3

Healthcare Student Stereotypes

Cook \& Stoecker

Journal of Research in Interprofessional Practice and Education

Vol. 4.2

November 2014 own stereotypes after the educational program.

- medical students' stereotypes of medical specialties.

Many articles that were captured with the original search were studies examining the effects of an educational intervention on student stereotypes. If the purpose of a study was to report only comparisons of the degree of change between pre- and postintervention stereotypes without identifying the specific stereotypes present, the study was not included. In addition, if a study compared changes in stereotypes of different groups of students at different stages in the same educational program and the purpose of the study was to discuss the differences of stereotypes at different points in the program, the study was not included.

\section{Results of article collection}

The initial database and reference list search resulted in 4,537 articles. Based on the large number of results from Medline and CINAHL, limits of human and adult or adolescent were applied, resulting in 2,628 studies. One hundred seventy-nine articles met the inclusion criteria based on title and abstract, and 86 were duplicates. Of the 93 remaining articles, 68 were excluded initially after a review of the title and abstract against the general exclusion criteria. Twenty-five full-text articles were reviewed and 11 were excluded based on the above specific exclusion criteria. Of the 15 remaining articles, three articles used the same data and asked similar questions, so two of these three articles were excluded, leaving 13 articles for the systematic review. The schematic presented in Figure 1 summarizes the process for determining the articles for review.

\section{Quality of evidence}

All of the included studies used surveys to capture stereotypes of healthcare students. Of the 13 articles selected, eight were cross-sectional survey studies, four were longitudinal before-and-after survey studies, and one was a modified experimental pretest post-test study design. The studies spanned the years 1991 to 2010. Twelve of the 13 studies used samples of convenience from one or two institutions, typically the institutions with which the authors were associated. One study identified 30 institutions of higher education throughout the U.S., and 28 responded as part of the study. Table 1 summarizes the included articles.
Figure 1

\section{Article collection schematic}

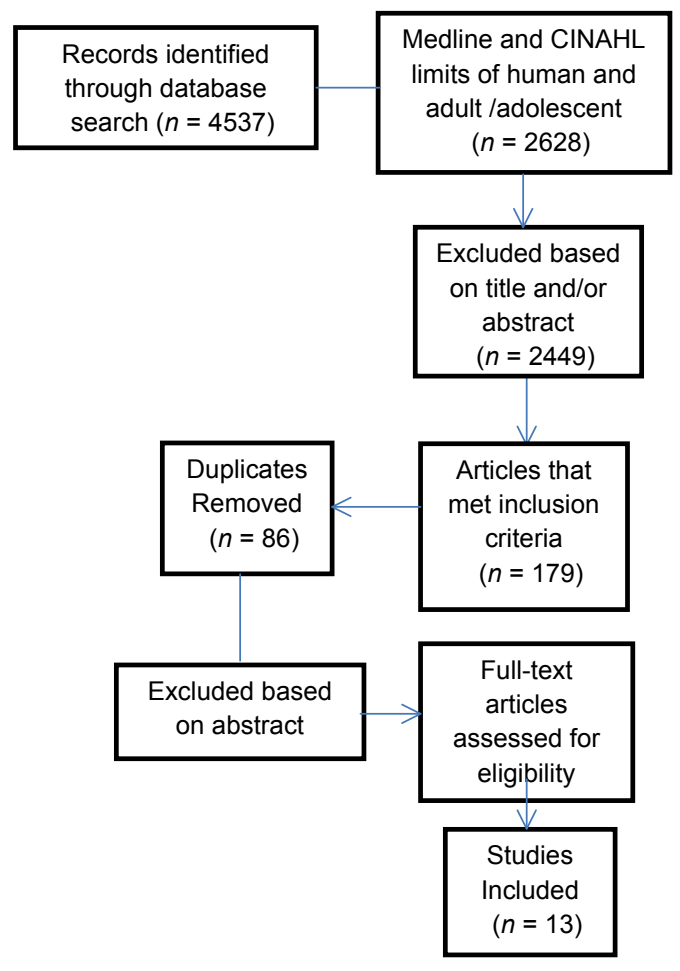


4

Healthcare Student Stereotypes

Cook \& Stoecker

Journal of Research in Interprofessional Practice and Education

Vol. 4.2

November 2014
Table 1

\section{Summary of articles}

\begin{tabular}{|c|c|c|c|c|c|c|}
\hline Title & Authors & Design & Country & $\begin{array}{l}\text { Sample } \\
\text { size }\end{array}$ & $\begin{array}{c}\text { Professions of } \\
\text { students in study }(n)\end{array}$ & Level of education \\
\hline $\begin{array}{l}\text { Stereotypes between physical } \\
\text { and occupational therapy } \\
\text { students }\end{array}$ & $\begin{array}{l}\text { Kamps } \\
\text { et al. [2] }\end{array}$ & $\begin{array}{l}\text { Cross- } \\
\text { sectional; } \\
\text { Survey }\end{array}$ & U.S. & $\begin{array}{l}687 \\
\text { students }\end{array}$ & $\begin{array}{l}\text { Physical Therapy (PT) } \\
\text { (372) and } \\
\text { Occupational Therapy } \\
\text { (0T) (315) }\end{array}$ & $\begin{array}{l}\text { Enrolled in } \\
\text { Baccalaureate PT or } \\
\text { OT program }\end{array}$ \\
\hline $\begin{array}{l}\text { A two-week stay in an } \\
\text { Interprofessional Training Unit } \\
\text { changes students' attitudes to } \\
\text { health professionals }\end{array}$ & $\begin{array}{l}\text { Jacobsen } \\
\text { et al. [10] }\end{array}$ & $\begin{array}{l}\text { Longitudinal; } \\
\text { Before and } \\
\text { after }\end{array}$ & Denmark & $\begin{array}{l}169 \\
\text { students }\end{array}$ & $\begin{array}{l}\text { Nursing (69), 0T (29), } \\
\text { PT (31), and Medicine } \\
\text { (33) }\end{array}$ & $\begin{array}{l}\text { Nursing, 0T, and PT } \\
\text { students in 4th-6th } \\
\text { semester; Medical } \\
\text { students in 8th } \\
\text { semester }\end{array}$ \\
\hline $\begin{array}{l}\text { Professional stereotyping and } \\
\text { interprofessional education }\end{array}$ & $\begin{array}{l}\text { Mandy } \\
\text { et al. [9] }\end{array}$ & $\begin{array}{l}\text { Prospective; } \\
\text { Longitudinal; } \\
\text { Before and } \\
\text { after }\end{array}$ & England & $\begin{array}{l}89 \\
\text { students }\end{array}$ & $\begin{array}{l}\text { Podiatry (28) and PT } \\
\text { (61) }\end{array}$ & $\begin{array}{l}\text { 1st semester of the } \\
\text { 1st year of study }\end{array}$ \\
\hline $\begin{array}{l}\text { Stereotyping between physical } \\
\text { therapy and occupational therapy } \\
\text { students }\end{array}$ & $\begin{array}{l}\text { Streed } \\
\text { et al. [1] }\end{array}$ & $\begin{array}{l}\text { Cross- } \\
\text { sectional; } \\
\text { Survey }\end{array}$ & U.S. & $\begin{array}{l}84 \\
\text { students }\end{array}$ & PT (42) and 0T (42) & $\begin{array}{l}3 \text { months into } 18- \\
\text { month curriculum }\end{array}$ \\
\hline $\begin{array}{l}\text { Stereotyping as a barrier to } \\
\text { collaboration: Does } \\
\text { interprofessional education make } \\
\text { a difference? }\end{array}$ & $\begin{array}{l}\text { Ateah } \\
\text { et al. [8] }\end{array}$ & $\begin{array}{l}\text { Modified } \\
\text { experimental; } \\
\text { Pre-test; } \\
\text { Post-test }\end{array}$ & Canada & $\begin{array}{l}51 \\
\text { students }\end{array}$ & $\begin{array}{l}\text { Medical }(23.5 \%), \\
\text { Nursing }(19.6 \%), 0 \mathrm{0T} \\
(13.7 \%), \text { PT }(13.7 \%), \\
\text { Dental hygiene (9.8\%), } \\
\text { Pharmacy }(11.8 \%), \\
\text { and Dentistry }(7.8 \%)\end{array}$ & $\begin{array}{l}\text { All students were pre- } \\
\text { licensure from all } \\
\text { years of the included } \\
\text { professional } \\
\text { programs }\end{array}$ \\
\hline $\begin{array}{l}\text { Interprofessional perceptions of } \\
\text { healthcare students }\end{array}$ & $\begin{array}{l}\text { Hind } \\
\text { et al. [11] }\end{array}$ & $\begin{array}{l}\text { Cross- } \\
\text { sectional; } \\
\text { Survey }\end{array}$ & $\begin{array}{l}\text { United } \\
\text { Kingdom }\end{array}$ & $\begin{array}{l}933 \\
\text { students }\end{array}$ & $\begin{array}{l}\text { Medical (350), Nursing } \\
\text { (390), Pharmacy (102), } \\
\text { PT (67), Dietetic (24) }\end{array}$ & $\begin{array}{l}\text { Within } 6 \text { weeks of } \\
\text { starting the } \\
\text { undergraduate } \\
\text { degree program }\end{array}$ \\
\hline $\begin{array}{l}\text { A comparative study of the } \\
\text { attitudes of nursing and medical } \\
\text { students to aspects of patient } \\
\text { care and the nurse's role in } \\
\text { organizing that care }\end{array}$ & $\begin{array}{l}\text { Ryan } \\
\text { et al. [16] }\end{array}$ & $\begin{array}{l}\text { Cross- } \\
\text { sectional; } \\
\text { Survey }\end{array}$ & $\begin{array}{l}\text { Northern } \\
\text { Ireland }\end{array}$ & $\begin{array}{l}31 \\
\text { students }\end{array}$ & $\begin{array}{l}\text { Nursing (19) and } \\
\text { Medical (12) }\end{array}$ & $\begin{array}{l}\text { Final year } \\
\text { undergraduate } \\
\text { nursing students, 4th } \\
\text { or final year medical } \\
\text { students }\end{array}$ \\
\hline $\begin{array}{l}\text { Characteristics of doctors and } \\
\text { nurses as perceived by students } \\
\text { entering medical school: } \\
\text { Implications for shared teaching }\end{array}$ & $\begin{array}{l}\text { Rudland } \\
\text { et al. [13] }\end{array}$ & $\begin{array}{l}\text { Cross- } \\
\text { sectional; } \\
\text { Survey }\end{array}$ & $\begin{array}{l}\text { New } \\
\text { Zealand }\end{array}$ & $\begin{array}{l}646 \\
\text { students }\end{array}$ & Medical (646) & $\begin{array}{l}\text { 1st week of } \\
\text { undergraduate } \\
\text { medical school course }\end{array}$ \\
\hline $\begin{array}{l}\text { Physical and occupational } \\
\text { therapy undergraduates' } \\
\text { stereotypes of one another }\end{array}$ & $\begin{array}{l}\text { Katz } \\
\text { et al. [7] }\end{array}$ & $\begin{array}{l}\text { Cross- } \\
\text { sectional; } \\
\text { Survey }\end{array}$ & U.S. & $\begin{array}{l}53 \\
\text { students }\end{array}$ & PT (25) and 0T (28) & $\begin{array}{l}\text { Senior year of } \\
\text { baccalaureate } \\
\text { program }\end{array}$ \\
\hline $\begin{array}{l}\text { Effects of nursing education on } \\
\text { the image of nursing as a } \\
\text { profession in Israel }\end{array}$ & $\begin{array}{l}\text { Ben Natan } \\
\text { [13] }\end{array}$ & $\begin{array}{l}\text { Cross- } \\
\text { sectional; } \\
\text { Survey }\end{array}$ & Israel & $\begin{array}{l}400 \\
\text { students }\end{array}$ & Nursing & $\begin{array}{l}\text { 1st year students and } \\
\text { 2nd - to 4th-year } \\
\text { students }\end{array}$ \\
\hline $\begin{array}{l}\text { Will opposites attract? } \\
\text { Similarities and differences in } \\
\text { students' perceptions of the } \\
\text { stereotype profiles of other } \\
\text { health and social care } \\
\text { professional groups }\end{array}$ & $\begin{array}{l}\text { Hean } \\
\text { et al. [3] }\end{array}$ & $\begin{array}{l}\text { Cross- } \\
\text { sectional; } \\
\text { Survey }\end{array}$ & England & 1426 & $\begin{array}{l}\text { Audiology (28), } \\
\text { Medical (177), } \\
\text { Midwives (13), } \\
\text { Nursing (600), 0T (73), } \\
\text { Pharmacy (130), PT } \\
\text { (75), Podiatry (38), }\end{array}$ & $\begin{array}{l}\text { Radiography (63), } \\
\text { Social Work (58) } \\
\text { 1st year students } \\
\text { surveyed at the } \\
\text { beginning of the } \\
\text { academic year }\end{array}$ \\
\hline $\begin{array}{l}\text { Doctors and nurses: Stereotypes } \\
\text { and stereotype change in } \\
\text { interprofessional education }\end{array}$ & $\begin{array}{l}\text { Carpenter } \\
\text { [5] }\end{array}$ & $\begin{array}{l}\text { Longitudinal; } \\
\text { Before and } \\
\text { after }\end{array}$ & $\begin{array}{l}\text { United } \\
\text { Kingdom }\end{array}$ & $\begin{array}{l}39 \\
\text { students }\end{array}$ & $\begin{array}{l}\text { Nursing (16) and } \\
\text { Medical (23) }\end{array}$ & Unknown \\
\hline $\begin{array}{l}\text { Student attitudes to } \\
\text { undergraduate interprofessional } \\
\text { education }\end{array}$ & $\begin{array}{l}\text { Tunstall- } \\
\text { Pedoe } \\
\text { et al. [12] }\end{array}$ & $\begin{array}{l}\text { Longitudinal; } \\
\text { Before and } \\
\text { after }\end{array}$ & $\begin{array}{l}\text { United } \\
\text { Kingdom }\end{array}$ & $\begin{array}{l}348 \\
\text { students }\end{array}$ & $\begin{array}{l}\text { Medical (232), Allied } \\
\text { Health Professions } \\
\text { (Diagnostic Radiography, } \\
\text { Therapeutic } \\
\text { Radiography, PT) and } \\
\text { Nursing (116) }\end{array}$ & 1st term students \\
\hline
\end{tabular}




\section{JRIPE}

5

Healthcare Student Stereotypes

Cook \& Stoecker

\section{Stereotyping scales}

The Health Team Stereotype Scale (HTSS) [1,2,4,7,9], the Attitudes to Health Professions Questionnaire (AHPQ) [10], the Health Care Stereotypes Scale [4,11-13], and the Student Stereotypes Rating Questionnaire (SSRQ) $[8,3]$ were used in 11 of the 13 studies.

The HTSS consists of 54 pairs of bipolar adjectives. The adjectives are rated from 1 (positive) to 7 (negative). The adjective pairs are listed randomly, and the respondents indicate their degree of agreement with the adjectives. Four studies used the HTSS and cited a reliability coefficient of .93 based on a 1981 study by Parker and Reisch $[1,2,7,9,14]$. Validity of the scale was not reported in these studies.

Samples of positive/negative adjective pairs from the HTSS:

$\begin{array}{lll}\text { Depreciated/Overrated } & \text { Broad/Narrow } & \text { Relaxed/Strict } \\ \text { Innovative/Conservative } & \text { Proud/Humble } & \text { Passive/Aggressive } \\ \text { Comprehensive/Narrow } & \text { Interesting/Dull } & \text { Casual/Intentional } \\ \text { Experienced/Inexperienced } & \text { Standing/Sitting } & \text { Attractive/Repulsive } \\ \text { Unusual/Repetitive } & \text { Fast/Slow } & \text { Gracious/Impolite } \\ \text { Independent/Subordinate } & \text { Strong/Weak } & \text { Superior/Average } \\ \text { Co-operative/Competitive } & \text { Original/Conventional } & \text { Clean/Dirty } \\ \text { Precise/Obscure } & \text { Active/Passive } & \text { Successful/Ineffective } \\ \text { Well-mannered/Overbearing } & \text { Creative/Contented } & \text { Conspicuous/Reserved }\end{array}$

The AHPQ consists of 20 items. The questionnaire items measure two dimensions: caring and subservient. Each item contains two opposite attributes that are anchors for the ends of a $10 \mathrm{~cm}$ visual scale (see examples below). The respondents indicate where they think a member of the profession in question fits on the $10 \mathrm{~cm}$ scale. Of the 13 studies included in this review, one used the AHPQ and reported the validation of the questionnaire from a 2005 study by Lindqvist et al. [10,15]. Reliability of the scale was not reported in these studies.

The adjectives used in the AHPQ include

Caring dimension

- Caring/Non-caring

- Empathetic/Non-empathetic

- Approachable/Non-approachable

- Values teamwork/Does not value teamwork

- Sympathetic/Non-sympathetic

- Thoughtful/Not thoughtful

- Flexible/Not flexible

- Patient-centred/Not patient-centred

- Not self-centred/Self-centred

- Gentle/Rough

- Not arrogant/Arrogant

- Practical/Theoretical

- Conciliatory/Not conciliatory
Subservient dimension

- Vulnerable/Confident

- Non-assertive/Assertive

- Does not value autonomy/Values autonomy

- Not technically-focused/Technically-focused

- Not independent/Independent
Journal of Research in

Practice and

Education

Vol. 4.2

November 2014 


\section{JRIPE}

6

Healthcare Student Stereotypes

Cook \& Stoecker

The Health Care Stereotypes Scale was created by a group of students brainstorming the characteristics of doctors and nurses. Four frequently mentioned positive and three frequently mentioned negative terms were chosen. A fourth negative term, "dogooder," was added as a control because it was considered not to be associated with either nurses or doctors. The respondents indicate the extent to which the trait or term applies to the given professional group on a scale from 1 (not at all applicable) to 7 (strongly applicable). Four studies used the Health Care Stereotypes Scale. These studies did not report reliability or validity of the scale [4,11-13].

The adjectives used in the Health Care Stereotypes Scale include

$\begin{array}{ll}\text { Positive adjectives } & \text { Negative adje } \\ \text { - Caring } & \text { - Arrogant } \\ \text { - Confident } & \text { - Detached } \\ \text { - Dedicated } & \text { - Dithering } \\ \text { - Good communicator } & \end{array}$

Lastly, the SSRQ, by Barnes et al. [6] with adaptations by Hean et al. [3], consists of nine characteristics. Respondents are asked to rate the group in question on each characteristic from 0 (very low) to 5 (very high). Two studies used the SSRQ and reported that content validity was established by a panel of academics, health and social care professionals, and pre-registration students. Test-retest reliability of each item on the questionnaire was tested, and items not reliable over time at a 5\% significance level were not used $[3,6,8]$.

The characteristics used in the SSRQ include

$\begin{array}{ll}\text { - Professional competence } & \text { - Confidence } \\ \text { - Leadership } & \text { - Academic ability } \\ \text { - Independence } & \text { - Interpersonal skills } \\ \text { - Team player } & \text { - Decision making } \\ \text { - Practical } & \end{array}$

The two remaining studies used other surveys. One study created a survey based on the aims of the study and completed their own validity and reliability studies. The internal reliability of the overall scale was found to be statistically high [16]. Validity was not reported. Lastly, one study used a survey created in a prior study by different authors. The reliability values of the items in this survey ranged from .823 to .831 , and the survey was validated by expert opinion [17].

\section{Results}

The surveys used in these studies examined a variety of stereotypes from caring/subservient to academic ability/competence, and some examined auto-stereotypes,

Journal of Research in Interprofessional Practice and Education

Vol. 4.2 November 2014 stereotypes about one's own profession, and hetero-stereotypes, stereotypes about other professions, while others included only hetero-stereotypes. Because of these differences, it is difficult to summarize the results of these studies or draw specific conclusions. However, there were some areas of consistency among studies that used the same scales. 
JRIPE

7

Healthcare Student Stereotypes

Cook \& Stoecker

Three of the four studies that used the HTSS studied physical therapy (PT) and occupational therapy (OT) students and had these students rate themselves as well as the other profession. In all three studies, the self-assessments of both OT and PT students were more positive than the profession's assessment of each other $[1,2,7]$. The fourth study included PT and podiatry students and did not examine the selfassessment component [9]. The two studies using the SSRQ found that students entering professional education rated physicians highest in the area of leadership, academic ability, confidence, and decision-making, and lowest in the area of team player. These same students ranked nurses lowest in the area of independence and highest in the area of team player, and rated pharmacists lowest on interpersonal skills $[3,8]$. The only consistent result from the four studies using the Health Care Stereotypes Scale was that medical students rated doctors high in caring [4,11-13].

Table 2

\section{Results from the HTSS}

\begin{tabular}{|c|c|c|c|}
\hline Title & Authors & $\begin{array}{l}\text { Professions } \\
\text { of students } \\
\text { in study ( } n \text { ) }\end{array}$ & Outcomes \\
\hline $\begin{array}{l}\text { Stereotypes } \\
\text { between } \\
\text { physical and } \\
\text { occupational } \\
\text { therapy students }\end{array}$ & $\begin{array}{l}\text { Kamps } \\
\text { et al. [2] }\end{array}$ & $\begin{array}{l}\text { PT (372) and } \\
\text { OT (315) }\end{array}$ & $\begin{array}{l}\text { - Both groups rate PT students positive on: standing, experienced, hard, well-to-do, } \\
\text { strict, difficult, heavy, aggressive, fast, authoritative, intentional } \\
\text { - Both groups rate } 0 \text { T students positive on: reserved, depreciated, humble, creative, } \\
\text { cooperative } \\
\text { - Each discipline viewed itself as more positive than the other discipline viewed it }\end{array}$ \\
\hline $\begin{array}{l}\text { Professional } \\
\text { stereotyping and } \\
\text { interprofessional } \\
\text { education }\end{array}$ & $\begin{array}{l}\text { Mandy } \\
\text { et al. [9] }\end{array}$ & $\begin{array}{l}\text { Podiatry (28) } \\
\text { and PT (61) }\end{array}$ & $\begin{array}{l}\text { - Four (7\%) podiatrist students' ratings of PT students were negative including humble, } \\
\text { overbearing, contented, dirty } \\
\text { - Nine (17\%) PT students' ratings of podiatrist students were negative including sitting, } \\
\text { repulsive, average, ineffective, strict, repetitive, slow, casual, impolite } \\
\text { - } 68.5 \% \text { of median podiatrist students' ratings of PT students were positive } \\
\text { - } 74.1 \% \text { of median PT students' ratings of podiatrist students were positive }\end{array}$ \\
\hline $\begin{array}{l}\text { Stereotyping } \\
\text { between } \\
\text { physical therapy } \\
\text { and occupational } \\
\text { therapy students }\end{array}$ & $\begin{array}{l}\text { Streed } \\
\text { et al. [1] }\end{array}$ & $\begin{array}{l}\text { PT (42) and } \\
\text { OT (42) }\end{array}$ & $\begin{array}{l}\text { - Negative adjectives PT students chose about } 0 \mathrm{~T} \text { students: passive, dull, narrow } \\
\text { - Negative adjectives } 0 \mathrm{~T} \text { students chose about PT students: overrated, competitive, strict } \\
\text { - Positive adjectives PT students chose about 0T students: casual, passive } \\
\text { - Positive adjectives } 0 \mathrm{~T} \text { students chose about PT students: proud, passive, obscure } \\
\text { - Each thought the other was conventional, conservative, and narrow } \\
\text { - PT and 0T students' self-assessments were more positive than the others disciplines' } \\
\text { assessment of them }\end{array}$ \\
\hline $\begin{array}{l}\text { Physical and } \\
\text { occupational } \\
\text { therapy } \\
\text { undergraduates' } \\
\text { stereotypes of } \\
\text { one another }\end{array}$ & $\begin{array}{l}\text { Katz } \\
\text { et al. [7] }\end{array}$ & $\begin{array}{l}\text { PT (25) and } \\
\text { OT (28) }\end{array}$ & $\begin{array}{l}\text { - Both student groups agreed PTs were more positive in: standing, independent, active, } \\
\text { strong, passive } \\
\text { - Both student groups agreed OTs were more positive in: conspicuous } \\
\text { - Each group viewed itself more positively than the other group viewed it }\end{array}$ \\
\hline
\end{tabular}

Journal of Research in Interprofessional Practice and Education

Vol. 4.2

November 2014
The three studies that did not include one of the surveys discussed above used surveys not seen in any other study. The study using the AHPQ reported that each group of students rated members of their own profession as more caring than students from any other group. Three of the four student groups rated members of their own profession as less subservient than students from any other group [10]. The other two studies examined stereotypes associated with the role of the nurse. One study found that nurs- 


\section{JRIPE}

8

Healthcare Student Stereotypes

Cook \& Stoecker

ing students were more likely than medical students to perceive the nurse's role as that of an independent practitioner [16]. The other examined characteristics that nursing students believe applied to the nursing profession using five qualities characteristic of Israeli nurses: cares for others, helps the doctor, intelligent, has a respectable profession, and highly moral [17]. Tables 2-6 summarize the results by survey used in each study.

Table 3

\section{Results from the AHPO}

\begin{tabular}{|c|c|c|c|}
\hline Title & Authors & $\begin{array}{l}\text { Professions } \\
\text { of students } \\
\text { in study }(n)\end{array}$ & Outcomes \\
\hline $\begin{array}{l}\text { A two-week stay } \\
\text { in an } \\
\text { Interprofessional } \\
\text { Training Unit } \\
\text { changes } \\
\text { students' } \\
\text { attitudes to } \\
\text { health } \\
\text { professionals }\end{array}$ & $\begin{array}{l}\text { Jacobsen } \\
\text { et al. [10] }\end{array}$ & $\begin{array}{l}\text { Nursing (69), } \\
\text { OT (29), PT } \\
\text { (31), and } \\
\text { Medicine (33) }\end{array}$ & $\begin{array}{l}\text { - Doctors least caring followed by PTs, OTs, and Nurses } \\
\text { - Nurses most subservient followed by OTs, PTs, and doctors } \\
\text { - Each group viewed members of their own profession as more caring than the } \\
\text { members of other professions } \\
\text { - OT students viewed OTs as significantly less subservient than they were seen by PT } \\
\text { and medical students } \\
\text { - PT students viewed PTs more caring and less subservient than the three other } \\
\text { professions perceived PTs to be } \\
\text { - Medical students viewed themselves as more caring and more subservient than the } \\
\text { three other professions perceived medical students to be } \\
\text { - Nursing students viewed nurses as more caring and less subservient than the three } \\
\text { other professions perceived nurses to be }\end{array}$ \\
\hline
\end{tabular}

Table 4

\section{Results from the Health Care Stereotypes Scale}

\begin{tabular}{|c|c|c|c|}
\hline Title & Authors & $\begin{array}{l}\text { Professions } \\
\text { of students } \\
\text { in study }(n)\end{array}$ & Outcomes \\
\hline $\begin{array}{l}\text { Interprofessional } \\
\text { perceptions of } \\
\text { healthcare } \\
\text { students }\end{array}$ & $\begin{array}{l}\text { Hind } \\
\text { et al. [11] }\end{array}$ & $\begin{array}{l}\text { Medical } \\
\text { (350), } \\
\text { Nursing } \\
\text { (390), } \\
\text { Pharmacy } \\
\text { (102), PT } \\
\text { (67), Dietetic } \\
\text { (24) }\end{array}$ & $\begin{array}{l}\text { - Dietetic students significantly more likely to give their profession higher ratings as } \\
\text { good communicators when compared with PT students } \\
\text { - Medical, nursing, and pharmacy students significantly more likely than PT students } \\
\text { to rate doctors as more caring } \\
\text { - Medical and pharmacy students significantly more likely than PT students to rate } \\
\text { doctors as good communicators } \\
\text { - Pharmacy students significantly more likely to give their profession higher ratings as } \\
\text { good communicators and caring than all other groups }\end{array}$ \\
\hline $\begin{array}{l}\text { Doctors and } \\
\text { nurses: } \\
\text { Stereotypes and } \\
\text { stereotype } \\
\text { change in } \\
\text { interprofessional } \\
\text { education }\end{array}$ & $\begin{array}{l}\text { Carpenter } \\
\text { [4] }\end{array}$ & $\begin{array}{l}\text { Nursing (16) } \\
\text { and Medical } \\
\text { (23) }\end{array}$ & $\begin{array}{l}\text { - Medical students perceived nurses as caring, dedicated, moderately good } \\
\text { communicators, and neither detached nor arrogant } \\
\text { - Nursing students perceived doctors as dedicated, confident, not dithering, and also } \\
\text { detached, arrogant, and poor communicators } \\
\text { - Medical students perceived doctors as confident, dedicated, caring, and arrogant, and } \\
\text { they were sure that doctors were not dithering } \\
\text { - Nursing students perceived nurses as caring, dedicated, good communicators, and } \\
\text { reasonably confident, and rejected the idea that nurses were arrogant, detached, and } \\
\text { dithering }\end{array}$ \\
\hline
\end{tabular}


9

Healthcare Student Stereotypes

Cook \& Stoecker
Journal of Research in Interprofessional Practice and Education

Vol. 4.2

November 2014
Table 4 (continued)

\section{Results from the Health Care Stereotypes Scale}

\begin{tabular}{|c|c|c|c|}
\hline Title & Authors & $\begin{array}{l}\text { Professions } \\
\text { of students } \\
\text { in study }(n)\end{array}$ & Outcomes \\
\hline $\begin{array}{l}\text { Characteristics of } \\
\text { doctors and } \\
\text { nurses as } \\
\text { perceived by } \\
\text { students } \\
\text { entering medical } \\
\text { school: } \\
\text { Implications for } \\
\text { shared teaching }\end{array}$ & $\begin{array}{l}\text { Rudland } \\
\text { et al. [13] }\end{array}$ & Medical (646) & $\begin{array}{l}\text {-1st year medical students perceived doctors and nurses as caring, confident, } \\
\text { dedicated, good communicators, non-dithering } \\
\text { - 1st year medical students were unsure if doctors and nurses were detached and } \\
\text { do-gooders } \\
\text {-3rd year medical students considered nurses to be inferior to their own profession in } \\
\text { respect to status in society, competence, and academic ability } \\
\text { - 3rd year medical students considered doctors to be significantly more confident, } \\
\text { arrogant, detached, and dedicated than nurses } \\
\text { - 3rd year medical students considered nurses to be more caring and more dithering } \\
\text { - 3rd year medical students perceived doctors to have more positive status in society, } \\
\text { more professional competence, and greater academic ability } \\
\text { - Life experience of doctors and nurses was perceived as comparable }\end{array}$ \\
\hline $\begin{array}{l}\text { Student } \\
\text { attitudes to } \\
\text { undergraduate } \\
\text { interprofessional } \\
\text { education }\end{array}$ & $\begin{array}{l}\text { Tunstall- } \\
\text { Pedoe } \\
\text { et al. [12] }\end{array}$ & $\begin{array}{l}\text { Medical } \\
\text { (232), Allied } \\
\text { Health } \\
\text { Professions } \\
\text { (AHP) and } \\
\text { Nursing (116) }\end{array}$ & $\begin{array}{l}\text { - } 80 \% \text { of all students rated medical students at high academic quality } \\
\text { - Medical students had a low perception of others' academic ability } \\
\text { - AHP and nursing students viewed doctors as less caring and dedicated, more } \\
\text { arrogant, practical, clever, and assertive, and not good team players or good } \\
\text { communicators compared to medical students views of doctors } \\
\text { - Medical students considered nurses to be "do-gooders," less practical, less assertive } \\
\text { than other students considered nurses to be } \\
\text { - AHP and nursing students had more favorable opinions of radiographers than } \\
\text { medical students } \\
\text { - AHP and nursing students used more positive adjectives to describe PTs than medical } \\
\text { students used to described PTs }\end{array}$ \\
\hline
\end{tabular}

\section{Results from the SSRO}

\begin{tabular}{|c|c|c|c|}
\hline Title & Authors & $\begin{array}{l}\text { Professions } \\
\text { of students } \\
\text { in study }(n)\end{array}$ & Outcomes \\
\hline $\begin{array}{l}\text { Will opposites } \\
\text { attract? } \\
\text { Similarities and } \\
\text { differences in } \\
\text { students' } \\
\text { perceptions of } \\
\text { the stereotype } \\
\text { profiles of other } \\
\text { health and social } \\
\text { care professional } \\
\text { groups }\end{array}$ & $\begin{array}{l}\text { Hean } \\
\text { et al. [3] }\end{array}$ & $\begin{array}{l}\text { Audiology } \\
\text { (28), Medical } \\
\text { (177), } \\
\text { Midwives } \\
\text { (13), Nursing } \\
\text { (600), OT } \\
\text { (73), } \\
\text { Pharmacy } \\
\text { (130), PT } \\
\text { (75), Podiatry } \\
\text { (38), } \\
\text { Radiography } \\
\text { (63), Social } \\
\text { Work (58) }\end{array}$ & $\begin{array}{l}\text { - Students clearly and strongly differentiated between the professional groups on the } \\
\text { characteristics of interpersonal skills and academic ability } \\
\text { - Clear distinction between professions on being a team player } \\
\text { - Some differentiation between professions on leadership and ability to make } \\
\text { decisions } \\
\text { - Differentiation low on characteristics of confidence; all groups rated medium to high } \\
\text { - All rated highly on professional competence }\end{array}$ \\
\hline $\begin{array}{l}\text { Stereotyping as a } \\
\text { barrier to } \\
\text { collaboration: } \\
\text { Does } \\
\text { interprofessional } \\
\text { education make } \\
\text { a difference? }\end{array}$ & $\begin{array}{l}\text { Ateah } \\
\text { et al. [8]. }\end{array}$ & $\begin{array}{l}\text { Medical } \\
(23.5 \%), \\
\text { Nursing } \\
(19.6 \%), \\
\text { OT }(13.7 \%), \\
\text { PT }(13.7 \%), \\
\text { Dental } \\
\text { hygiene } \\
(9.8 \%), \\
\text { Pharmacy } \\
(11.8 \%), \text { and } \\
\text { Dentistry } \\
(7.8 \%)\end{array}$ & $\begin{array}{l}\text { - Only physicians were rated high on leadership } \\
\text { - All professions except nursing were rated high on independence } \\
\text { - Physicians and pharmacists rated highest on professional competence } \\
\text { - Nursing rated highest as team players } \\
\text { - Physicians and dentists were the only professions not rated high as team players } \\
\text { - Interpersonal skills low for pharmacy, dentistry, and medicine } \\
\text { - All professions rated high on practical skills } \\
\text { - All professions rated high on confidence, physicians rated the highest } \\
\text { - All professions except dental hygiene rated high on academic ability }\end{array}$ \\
\hline
\end{tabular}


10

Healthcare Student Stereotypes

Cook \& Stoecker
Journal of Research in Interprofessional Practice and Education

Vol. 4.2

November 2014
Table 6

\section{Results from study-specific scales}

\begin{tabular}{|l|l|l|l|l|}
\hline Title & Authors & Scale & $\begin{array}{l}\text { Professions } \\
\text { of students } \\
\text { in study }(\boldsymbol{n})\end{array}$ & Outcomes \\
\hline $\begin{array}{l}\text { A comparative } \\
\text { study of the } \\
\text { attitudes of } \\
\text { nursing and } \\
\text { medical } \\
\text { students to } \\
\text { aspects of } \\
\text { patient care and } \\
\text { the nurse's role } \\
\text { in organizing } \\
\text { that care }\end{array}$ & $\begin{array}{l}\text { Ryan } \\
\text { et al. [16] }\end{array}$ & $\begin{array}{l}31 \text {-item } \\
\text { Likert-type } \\
\text { questionnaire } \\
\text { constructed } \\
\text { with the aims } \\
\text { and objectives } \\
\text { of the study in } \\
\text { mind }\end{array}$ & $\begin{array}{l}\text { Nursing (19) } \\
\text { and Medical } \\
(12)\end{array}$ & $\begin{array}{l}\text { - Eight medical students (72.8\%) rated in midrange on the nurse's } \\
\text { role as independent practitioner, 16 nursing students (84.2\%) } \\
\text { rated in the higher ranges } \\
\text { - Nursing students were more likely than medical students to } \\
\text { perceive the nurse's role as that of an independent practitioner } \\
\text { - Most nursing students and a small \% of medical students agreed } \\
\text { with the following statement: Nurses should refuse to carry out } \\
\text { any order which they felt was not in the patient's best interest }\end{array}$ \\
\hline $\begin{array}{l}\text { Effects of } \\
\text { nursing } \\
\text { education on } \\
\text { the image of } \\
\text { nursing as a } \\
\text { profession in } \\
\text { Israel }\end{array}$ & Ben Natan & $\begin{array}{l}\text { Questionnaire } \\
\text { developed } \\
\text { based on } \\
\text { previous study } \\
\text { by different } \\
\text { authors } \\
\text { (Tzeng, 2006) }\end{array}$ & $\begin{array}{l}\text { Nursing } \\
\text { (400) }\end{array}$ & $\begin{array}{l}\text { - Five qualities found to be characteristic of Israeli nurses: cares for } \\
\text { others, helps the doctor, intelligent, has a respectable profession, } \\
\text { highly moral (rank order) } \\
\text { - Participants want nurses to have the following image: highly } \\
\text { knowledgeable, has a respected profession, cares for others, } \\
\text { intelligent, courageous }\end{array}$ \\
\hline
\end{tabular}

\section{Discussion}

The purpose of this study was to systematically review the literature to determine what stereotypes about healthcare students and practitioners are held by healthcare students. The results of this review demonstrate that students of various healthcare professions hold stereotypes using both positive and negative adjectives to describe their own and other healthcare professions. Stereotyping is a natural process and can be an effective mechanism with which to organize information [1-3]. However, stereotypes can have negative effects on group interaction if based on inaccurate perceptions of others [3].

In the healthcare student stereotyping studies that used scales with a self-assessment component, students generally rated their own profession more positively than other professions. This is consistent with a study by Hind et al. [11] that demonstrated that individuals who identify strongly and positively with their own profession (their professional in-group) will rank another profession (the out-group) more negatively. The result of this may be an unwillingness to engage in interprofessional learning with students of other professions [11]. It may be one's ignorance of the outgroup that leads to an assumption that the out-group's profession is different from the in-group [18]. If such ignorance is present, it may be likely that students rate their own professions more positively than other professions, as they may have more knowledge of their chosen profession. Students may benefit from increased awareness of why they rate their own professions more positively, and from encouragement to look for the similarities with other professions. Learning about the out-group can create feelings of common identification that may help with students' willingness to learn collaboratively [19]. Educators engaged in interprofessional 
11

Healthcare Student Stereotypes

Cook \& Stoecker

Journal of Research in Interprofessional Practice and Education

Vol. 4.2 November 2014 learning may wish to include knowledge of the other health professions early in the interprofessional curriculum.

It is important to examine student stereotypes throughout professional education programs because students may bring these stereotypes into practice upon graduation $[1,2,3,7,8]$. The literature describes stereotypes held by practicing healthcare professionals that parallel some of the literature on student stereotypes. In studies examining stereotypes of practicing nurses and physicians, physicians were rated high in areas such as leadership, confidence, decision making, and academic ability. Physicians were consistently rated low in the area of caring. Nurses were ranked low in independence and high in the area of team player [3,20-22]. The results of these studies are similar to the results seen in studies examining healthcare student stereotypes, indicating that stereotypes developed before or during healthcare education may be carried over into practice [1-3,7,8]. These stereotypes may have effects on interprofessional collaboration $[3,4,23,24]$.

One example of the effect of stereotyping on collaboration among practicing healthcare providers may be seen in the area of decision-making. A repeated issue in the literature on the nurse-physician relationship involves physicians taking a more active role in patient care decisions [3,20-22]. One reason for this may be stereotyping. If physicians are generally seen as confident leaders with good decision-making skills and high academic ability, team members from other professions may relinquish some decision making to physicians or be less assertive or confident in discussing patient cases with physicians. In addition, other professions may unknowingly communicate these stereotypes to patients by consistently looking to physicians for decisions about patient care without providing input or questioning physicians [3,20-22]. Physicians were ranked lower in caring by other healthcare professionals, which may affect interprofessional collaboration in that other professions may feel the need to take on more responsibility than they typically would for being caring while letting go of some of the responsibility for making patient care decisions, especially if the decisions that need to be made are difficult for patients [21].

It is difficult to know where these stereotypes originate and what practice components reinforce these stereotypes; however, several authors have discussed mechanisms that may perpetuate stereotypes among healthcare professions. For example, nurses may not believe that their role in the healthcare team includes relinquishing decision-making responsibilities to physicians; however, MacKay [21] argues that working with physicians may lead to this behaviour if doctors do not believe that nurses can or should contribute. If nurses hold stereotypes about physicians, for example that physicians are confident leaders and decision makers with high academic ability, this may also contribute to a subservient role of nurses even if nurses do not believe that their role should be subservient [21]. In addition, if nurses are aware of stereotypes held of them by other professions, this may affect their selfimage and may actually change nurses' behaviour in practice [3]. Hilton and Von Hippel [25] give a possible explanation for this phenomenon, labelling it a self-fulfilling prophecy. They argue that negative expectations of a profession can become reality through the process of a self-fulfilling prophecy. 
Healthcare Student Stereotypes

Cook \& Stoecker

Journal of Research in Interprofessional Practice and Education

Vol. 4.2 November 2014

\section{Journal of Research in Interprofessional Practice and Education}

This suggests that in order to prevent inappropriate stereotypes from interfering with collaboration, it is important that all members of the interprofessional team hold accurate stereotypes about themselves, accurate stereotypes about the other professions, and believe that the other professions hold accurate stereotypes. Collaboration may not be positively impacted if only some of the professions involved in interprofessional collaboration have been educated on stereotyping. Auto-stereotypes and hetero-stereotypes of all professions involved in collaboration are factors in whether stereotypes will interfere with or enhance interprofessional collaboration. Accurate information about the professions is vital to this process. Healthcare students and practitioners should be educated about each unique role on the healthcare team in order to develop accurate stereotypes and use them in a way that facilitates communication and collaboration $[1,3,8]$. Healthcare facilities and educators can facilitate discussions of stereotyping among healthcare students and practitioners, and learning with, from, and about one another to encourage interprofessional collaboration $[2,8]$.

Future research should examine what stereotypes and attitudes most affect collaboration because the effect of stereotypes or attitudes such as clean, dirty, strong, and weak may affect students' willingness and ability to collaborate on a professional level differently than stereotypes or attitudes that appear to be more related to healthcare, such as caring/non-caring, patient-centred/not patient-centred. Further research in this area may lead to more information about which stereotypes affect interprofessional collaboration, and survey tools collecting data on those specific stereotypes can then be developed. Efforts could then be made to address those stereotypes in a way that facilitates and encourages interprofessional collaboration.

One limitation of this review is that it includes only quantitative studies. Mixedmethod and qualitative studies were not included in order to avoid the authors' interpretation of survey responses and inadvertently interjecting bias. There are studies in this area that used qualitative or mixed-method designs that may provide pertinent information on student stereotypes. Future research could include a systematic review of qualitative and mixed-method studies.

This review confirms that healthcare students hold stereotypes of their own and other healthcare professions upon entry into and throughout their professional education programs. Multiple instruments were used in these studies, students of different professions were surveyed, and the students were at different points in their education. This variety makes it difficult to summarize the results of these studies and draw conclusions. However, identifying stereotypes among healthcare students and confirming that stereotypes are present as early as upon entry into healthcare education can assist educators and researchers in discovering and developing techniques to guide student stereotypes toward promoting collaboration in the classroom and in practice.

\section{References}

1. Streed, C.P., \& Stoecker, J.L. (1991). Stereotyping between physical therapy and occupational therapy students. Physical Therapy, 71(1), 16-24. 
13

Healthcare Student Stereotypes

Cook \& Stoecker

Journal of Research in Interprofessional Practice and Education

Vol. 4.2

November 2014
2. Kamps, J., Page, R., Seagrave, C., Sweet, M., Zettergren, K., \& MacKinnon, J.M. (1996). Stereotypes between physical and occupational therapy students. Journal of Physical Therapy Education, 10(1), 18-21.

3. Hean, S., MacLeod, C., Adams, K., \& Humphris, D. (2006). Will opposites attract? Similarities and differences in students' perceptions of the stereotype profiles of other health and social care professional groups. Journal of Interprofessional Care, 20(2), 162-181.

4. Carpenter, J. (1995). Interprofessional education for medical and nursing students: Evaluation of a programme. Medical Education, 29, 265-272.

5. Carpenter, J., \& Hewstone, M. (1996). Shared learning for doctors and social workers: Evaluation of a programme. British Journal of Social Work, 26, 239-257.

6. Barnes, D., Carpenter, J., \& Dickinson, C. (2000). Interprofessional education for community mental health: Attitudes to community care and professional stereotypes. Social Work Education, 19, 565-583.

7. Katz, J.S., Moji Titiloye, V., \& Balogun, J.A. (2001). Physical and occupational therapy undergraduates' stereotypes of one another. Perceptual and Motor Skills, 92, 843-851.

8. Ateah, C.A., Snow, W., Wener, P., MacDonald, L., Metge, C., Davis, P., Fricke, M., Ludwig, S., \& Anderson, J. (2010). Stereotyping as a barrier to collaboration: Does interprofessional education make a difference? Nurse Education Today, 31, 208-213.

9. Mandy, A., Milton, C., \& Mandy, P. (2004). Professional stereotyping and interprofessional education. Learning in Health and Social Care, 3(3), 154-170.

10. Jacobsen, F., \& Lindqvist, S. (2009). A two-week stay in an interprofessional training unit changes students' attitudes to health professionals. Journal of Interprofessional Care, 23(3), 242-250.

11. Hind, M., Norman, I., Cooper, S., Gill, E., Hilton, R., Judd, P., \& Jones, S.C. (2003). Interprofessional perceptions of health care students. Journal of Interprofessional Care, 17(1), 21-34.

12. Tunstall-Pedoe, S., Rink, E., \& Hilton, S. (2003). Student attitudes to undergraduate interprofessional education. Journal of Interprofessional Care, 17(2), 161-172.

13. Rudland, J.R., \& Mires, G.J. (2005). Characteristics of doctors and nurses as perceived by students entering medical school: Implications for shared teaching. Medical Education, 39, 448-455.

14. Parker, H.J., \& Reisch, J.S. (1981). Employment and rehabilitation counselors characterize one another using stereotypes. Journal of Employment Counseling, 14, 99-107.

15. Lindqvist, S., Duncan, A., Shepstone, L., Watts, F., \& Pearce, S. (2005). Development of the Attitudes to Health Professionals Questionnaire (AHPQ): A measure to assess interprofessional attitudes. Journal of Interprofessional Care, 19, 269-279.

16. Ryan, A.A., \& McKenna, H.P. (1994). A comparative study of the attitudes of nursing and medical students to aspects of patient care and the nurse's role in organizing that care. Journal of Advanced Nursing, 19, 114-123.

17. Ben Natan, M. (2009). Effects of nursing education on the image of nursing as a professional in Israel. International Journal of Nursing Education Scholarship, 6(1), 1-13.

18. Stephan, W.G., \& Stephan, C.W. (1984). The role of ignorance in intergroup relations. In Miller, N., \& Brewer, M.B. (Eds.), Groups in contact: They psychology of desegregation. (pp. 229-255). Orlando FL: Academic Press.

19. Pettigrew, T.F. (1997). Generalized intergroup contact effects on prejudice. Personality and Social Psychology Bulletin, 23, 173-185.

20. MacKay L. (1993). Conflicts in care, medicine and nursing. London: Chapman \& Hall.

21. MacKay L. (1995). The patient as a pawn in interprofessional relationships. In Soothill, K., MacKay, L., \& Webb, C. (Eds.), Interprofessional relations in health care. London: Edward Arnold.

22. Walby, S., Greenwell, J., MacKay, L., \& Soothill, K. (1994). Medicine and nursing: Professions in a changing health service. London: Sage.

23. Haslam, S.A., Turner, J.C., Oakes, P.J., Reynolds, K.J., \& Doosje, B. (2002). From personal pictures in the head to collective tools in the world: How shared stereotypes allow groups to represent and change social reality. In McGarty, C., Yzerbyt, V.Y., \& Spears, R. (Eds.), Stereotypes as explanation: The formation of meaningful beliefs about social groups (pp. 157-185). Cambridge, UK: Cambridge University Press.

24. Kirkham, M., Stapleton, H., Curtis, P., \& Thomas, G. (2002). Stereotyping as a professional defense mechanism. British Journal of Midwifery, 10, 549-552.

25. Hilton, J.L., \& Von Hippel, W. (1996). Stereotypes. Annual Review of Psychology, 47, 237-271. 